\title{
Spatial and Temporal Analysis of Land-use Changes Associated with Past Mining in the Kitakyushu District, Japan
}

\author{
Sungsu Rhee ${ }^{1}$ Marisa Mei Ling ${ }^{2}$ Junboum Park ${ }^{3 *}$ \\ ${ }^{1}$ Waste-to-Energy Research Division, Environmental Resources Research Department, National Institute of Environmental \\ Research, Environmental Research Complex, Korea \\ ${ }^{2}$ Geodetic and Geomatics Engineering Department, Institute Technology Bandung, Indonesia \\ ${ }^{3}$ Department of Civil and Environmental Engineering, Seoul National University, Korea
}

\begin{abstract}
In the beginning of $20^{\text {th }}$ century, the coal mining industry had an important role in Japan at which two-thirds of the coal product came from the Kitakyushu-Chikuho District (KCD). As a consequence of mining activities, land-use condition in this district showed notable changes. This paper presented a study of land-use changes in coal mining area by characterizing land-use pattern transition over the last 100 years. In order to carry out the rigorous analysis of land-use, a series of land-use maps over the last 100 years was developed using geographic information systems (GIS). The historic topographic map and another available old data were used to investigate the long-term changes of land-use associated with past mining within the GIS platform. The results showed that the utilization of a series of developed land-use maps successfully indicated the difference of land-use pattern in the KCD before and after the peak of mining activities. The general findings from land-use analysis described that forest and farm lands were lost and turned into abandoned sites in the last 100 years.
\end{abstract}

Key words : Spatial and temporal analysis, Geographic information systems (GIS), Land-use, Coal mining, Long term change

\section{Introduction}

The coal fields in the Kitakyushu district, Japan, were discovered in the $15^{\text {th }}$ century and developed in the $18^{\text {th }}$ century where coal was produced for domestic use. In the beginning of the $20^{\text {th }}$ century, coal industries had an important role as a major energy supplier for the overall Japanese economical development, and production of coal at that time increased at an accelerated rate (Okuno-Fujiwara, 1991). During mining operation, farm or forest land had been disappeared due to the surface facilities related to coal mining. It appeared that coal processing facilities, power plants, waste heaps, retention ponds, etc. occupied significant land spaces and destructed land surface (Chadwick et al., 1987). At the same time, during the development, coal industry attracted workers from rural areas, settling right next to their place of work, established urban infrastructure. Hence, it can be said that coal extraction is closely connected with land consumption and urban development (Genske, 2003; Richards and Palmer, 1993). In the last 100 years, land-use in the Kitakyushu-Chikuho District (KCD), which is one of the biggest coal mining development areas in Japan, has shown notable changes as consequences of mining activities (Shapira, 1990). Nowadays, Japan has only a few underground coal mines in operation and approximately a thousand mines are either inactive or abandoned. The reasons are not so much due to the shortage of coal reserves, but rather for preventing from land damages. Most of the damages are due to extraction of coal seams that could cause the surface subsidence. Moreover, discharging water from the mining area and the accumulation of waste stones could cause environmental problems in several districts (Esaki, 2003).

Environmental processes are inherently spatial and could not be fully understood without taking into account their

*Corresponding author : Junbpark@snu.ac.kr

원고접수일 :2013.5.21 심사일 :2013.8.2 게재승인일 :2013.8.2

질의 및 토의 :2013.10.31 까지 
spatial dimensions (Aspinall and Pearson, 2000). The relationship between human and the environment cannot be represented without a reference to a spatial location, since the environment is described by the topological relationships among physical objects (e.g. land-use composition in a given space-time location), and human activities produce impacts spatially on the environment (Champagna, 2006). In order to explain the spatial and temporal land-use changes in the $\mathrm{KCD}$, therefore, an effective methodology should be developed to obtain comprehensive analysis of land-use transition as consequences of long history of coal mining activities. Geographic Information System (GIS) is an ideal method for analyzing the impact of mining development and land-use changes, since the geography is the playing field, literally, on which these dynamics unfold (Longley et al., 2001). Moreover, spatial and non spatial information, often for very different purposes, can be integrated and analyzed to visualize relationships, find explanations, and develop solutions.

The objective of this paper is to analyze the phenomena of land-use changes in the $\mathrm{KCD}$, which relates to the influence of past coal mining activities, spatially and temporally using GIS. In this paper, land-use changes in the KCD was studied by identifying land-use pattern transition over the last 100 years that leads to the apparent of barren land (abandoned sites) related to coal mining industry. A series of landuse maps was developed from $1: 50,000$ old topographical maps based on $100 \mathrm{~m}$ mesh scale using GIS. The new landuse information in 1900 and 1950 was created and compiled with land-use database of 1976 and 1997, which was published by Ministry of Land, Infrastructure, and Transport of Japan (MLIT), to form a series of land-use maps over the last 100 years.

\section{Material and Methods}

\subsection{Study area}

The study area is nearly $1,650 \mathrm{~km}^{2}$ at the KCD in the Fukuoka Prefecture, Japan (Fig. 1). In this district, there is an area extracted at the beginning of vast development of coal industry in 1900. Inside the extracted area, the elevation ranges from 0 to $248 \mathrm{~m}$ above sea level with $39 \mathrm{~m}$ of the mean elevation (Fig. 2).

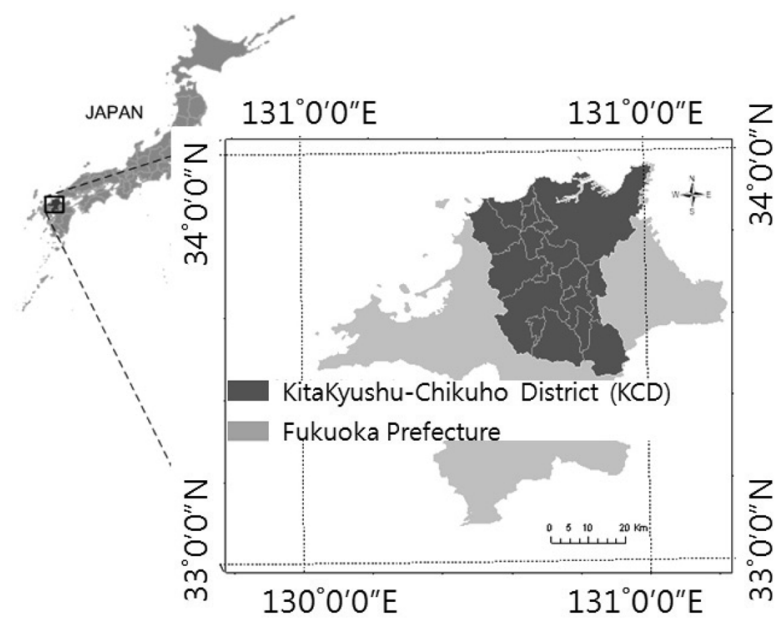

Fig. 1. Description of the Kitakyushu-Chikuho District (KCD).

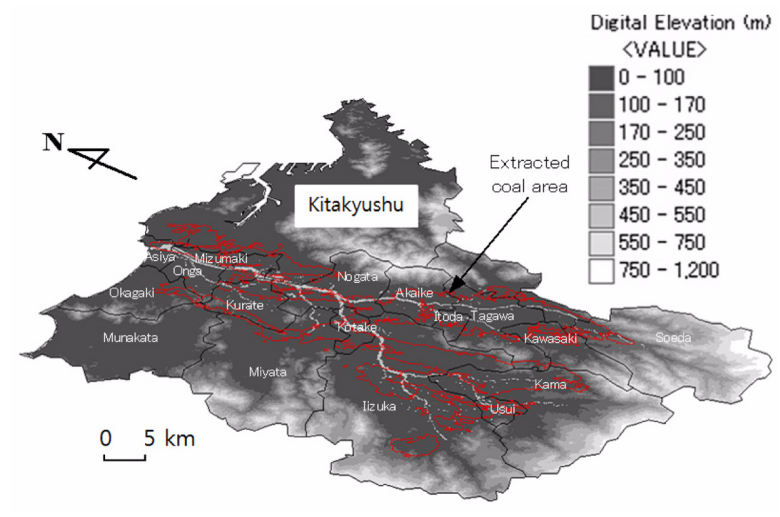

Fig. 2. Surface elevation model of the KCD at the level of $50 \mathrm{~m}$.

Land-use composition of Fukuoka Prefecture is characterized by Fukuoka and the Kitakyushu Districts where largescale urbanization has occurred after the World War II; the Chikuho District where the land-use has changed extremely due to urban development from the decline of coal mining industries; and the Chikugo District where the old agriculture area has still remained. The Chikuho District, which is characterized by the Onga River basin including Nogata city, Iizuka city, Tagawa city, etc., was determined by Japanese government law on temporary measures of coal mining area development. In the Chikuho District, coal mining was developed particularly from 1900 to 1960 in the area that had been previously rice field before 1900 . Thereafter, coal mining industries were shut down one by one due to the cheap and good quality of coal that was imported from overseas and also because of the energy revolution. This situa- 


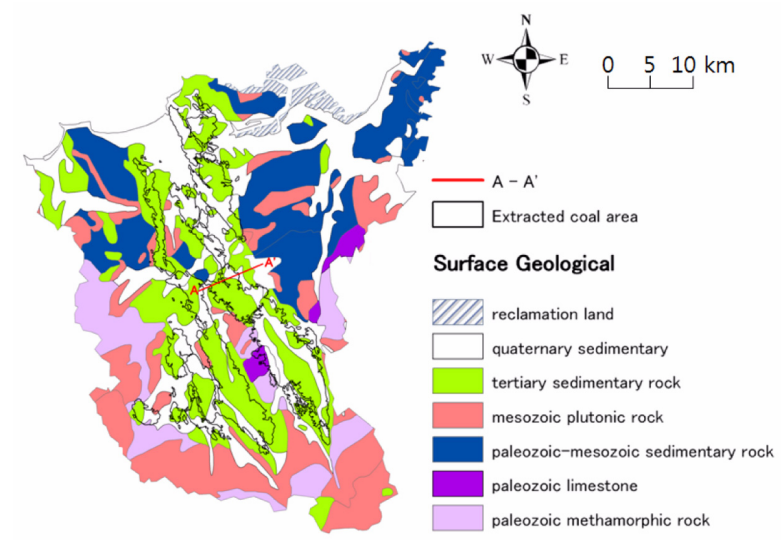

Fig. 3. Surface geology of the KCD.

tion has seriously been problems in the reuse of the land because such colliery facilities waste heaps, ponds, etc. have remained. These problems still exist until today even though the government has promoted the growth and development of mining law to protect the area left by coal mining operations. Thus, the study area of this study is defined to include Chikuho, Kitakyushu and some part of Fukuoka District, which is called as KCD, based on the division of administrative boundary of Fukuoka Prefecture and the area in the Onga River basin. Geographically, the KCD is located between the latitude of $33^{\circ} 26^{\prime} 50^{\prime \prime} \mathrm{N}-33^{\circ} 58^{\prime} 11^{\prime \prime} \mathrm{N}$ and the longitude of $130^{\circ} 28^{\prime} 37^{\prime \prime} \mathrm{E}-131^{\circ} 01^{\prime} 26^{\prime \prime} \mathrm{E}$.

The surface geology of the KCD was depicted in Fig. 3. The geology of the KCD consisted of quaternary sedimentary layer, tertiary sedimentary rock, mesozoic plutonic rock, paleozoic-mesozoic sedimentary rock, paleozoic limestone, paleozoic metamorphic rock, and reclaimed land. In the Southern part of the KCD, mesozoic-plutonic rock dominated the hilly mountains area around Usui, Kama, and Soeda. Paleozoic-mesozoic sedimentary rocks were found in Kitakyushu, Munakata, and Miyata area, whereas limestone deposits were found around Kitakyushu and a few deposit in Tagawa area. Additionally, some part of the sea has been reclaimed to become port land in the north side of Kitakyushu. In the extracted area, bedrock geology consisted predominantly of alluvial (quaternary sedimentary layer), tertiary sedimentary including coal seams, granite, and limestone bed. Moreover, in this extracted area, most of tertiary sedimentary area was located beneath the quaternary sedimentary layer. Fig. 3 shows one of the cross sections of strata

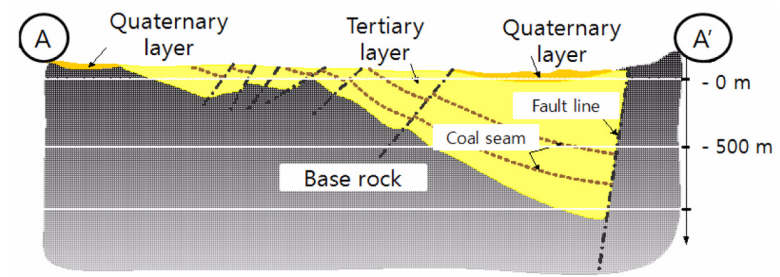

Fig. 4. Cross section of strata layer in the extracted area (A-A').

layer in the extracted area where tertiary sedimentary rock was located beneath the quaternary sedimentary layer. From the cross section A-A', it was shown in Chikuho coalfield that the main direction of coal seams consisted of multi layers deposits between tertiary sedimentary rocks with the strike of $\mathrm{N} 20^{\circ}-30^{\circ} \mathrm{SW}$ and the dip of $10^{\circ}-20^{\circ} \mathrm{NE}$ according to some observations. The outcrop of coal seams, which were mostly in the tertiary sedimentary rock, exposed to the surface mostly in hilly terrain area of formerly forest land. Coal was firstly extracted in this area whereas coal seam layer lied beneath the quaternary layer along the Onga River basin was also extracted.

\subsection{Selection of ages and data source for land-use development}

In this research, the historical background of the study area was set for one century due to the availability of old topographic maps, then it was decided to make land-use maps of 1900 and 1950. These were compared with the numerical land-use database of the MLIT from 1976 to 1997 to clarify land-use changes over the last 100 years.

By referring the age of the available old topographic maps and numeric data, it was decided to select the map of four ages of 1900, 1950, 1976, and 1997. Year 1900 was considered as the benchmark time when the modernization of government policy, the wealth and military strength, and the development of new industry, had been started to develop. However, there was no distinguished movement in Fukuoka Prefecture in 1900 except the construction of railway and the establishment of a government-owned Yahata ironworks in 1901. Moreover, the oldest topographic maps with $1: 50,000$ scales were firstly arranged in 1900. In 1950, after the end of World War II, the population doubled from 44 million in 1900 to 84 million in 1950 , and hit the delimitation that passed the development at the period during half a century 
of Taisho era, Showa era, and prewar days. The information of land-use condition before high economic growth can be observed from this year. Moreover, the topographic maps published at this time were made over the whole country based on the aerial photograph of the US Army. The distortion of society from the concentration of population and the pollution to the city due to large-scale development was actualized in 1976 when the high economic growth period was ended by oil crisis. The populations in the major cities were significantly increased, and the population of Japan became over 110 million. Moreover, the energy revolution from coal to oil triggered the shutdown of domestic coal mining, one by one. The first numerical land-use information with $100 \mathrm{~m}$ mesh scale by the MLIT has been opened to the public at this year. The latest numeric land-use information by the MLIT was made in 1997. It showed that the change of land-use caused after high economic growth ended.

\subsection{GIS methods}

The divisions of land-use were determined by land-use boundary lines of old topographic maps. However, the map symbols of the old edition topographic maps were not as clear as the present ones. It was difficult to subdivide the land-use categories equally to the digital land-use mesh created after 1976. Therefore, the divisions of land-use were assumed and reclassified into six categories such as agriculture, forest, urban (including villages), river, seashore, and sea. In the determination of land-use divisions from the old topographic map, some exceptions and assumptions were made because of the limitation of the old map. In the old topographic map, mulberry field, orchard, and tea field were blended together as agricultural land, since the field and the rice field could not be divided. The village, which was defined as a region where buildings were built, was established as colliery, factory, school, and etc. These features could not be distinguished on the old topographic map, so that they were brought together as urban area. The broadleaves forest and coniferous forest were brought together as forest. As the river data in 1976 and 1997 were not changed, it was assumed that river was not changed during 100 years. Furthermore, since the river's shape could not be specified in the old topographic map, therefore the land-use division

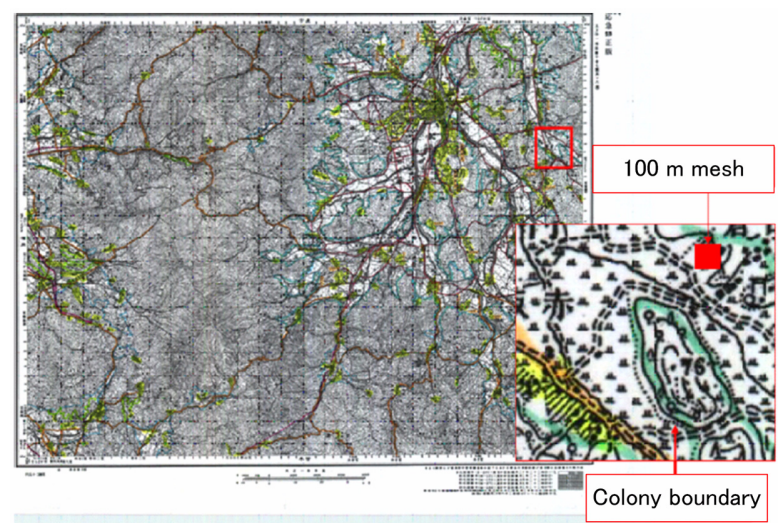

Fig. 5. Sample of old topographic paper map with $1: 50,000$ scales in 1900.

of the river in 1900 and 1950 is taken from the river shape in 1976. Moreover, colony boundary (dotted line) in the old topographic map was assumed as a basic boundary of the land-use divisions. The colony boundary was the land-use symbol of Meiji Era. This boundary was already shown in the topographic map developed in 1900 and the map made after 1903. In the old topographic paper map, the boundary line could not be connected, since the part of colony boundary was overlaid by characters or the name of place. A sample of old topographic paper map with $1: 50,000$ scales in 1900 was shown in Fig. 5.

In the GIS process, the old topographic paper maps were converted into digital images by the digital scanner. Landuse divisions were extracted from digital images through onscreen digitizing by utilizing GIS drawing function. In the digitizing process, however, the positional accuracy of a map was a function of the scale at which a map was created. Typically, maps can be accurate to roughly one line width (about $0.5 \mathrm{~mm}$ ), and the original material of the old topographical map of $1: 50,000$ had a positional accuracy of $25 \mathrm{~m}$, when it was converted into the actual distance (Tomlinson, 2003). Moreover, the final land-use map had the maximum tolerable error of $6.25 \%$ or 0.0625 ha within one hectare area, and one mesh is assumed as about one hectare area. Therefore, the scanned image was zoomed as much as possible during the digitizing, and close attention was paid on the centre line of land-use divisions' boundary in the old topographical map. The GIS process of making land-use maps was shown in Fig. 6 and the process of intersecting, calculating area, and conversion from land-use polygon into 


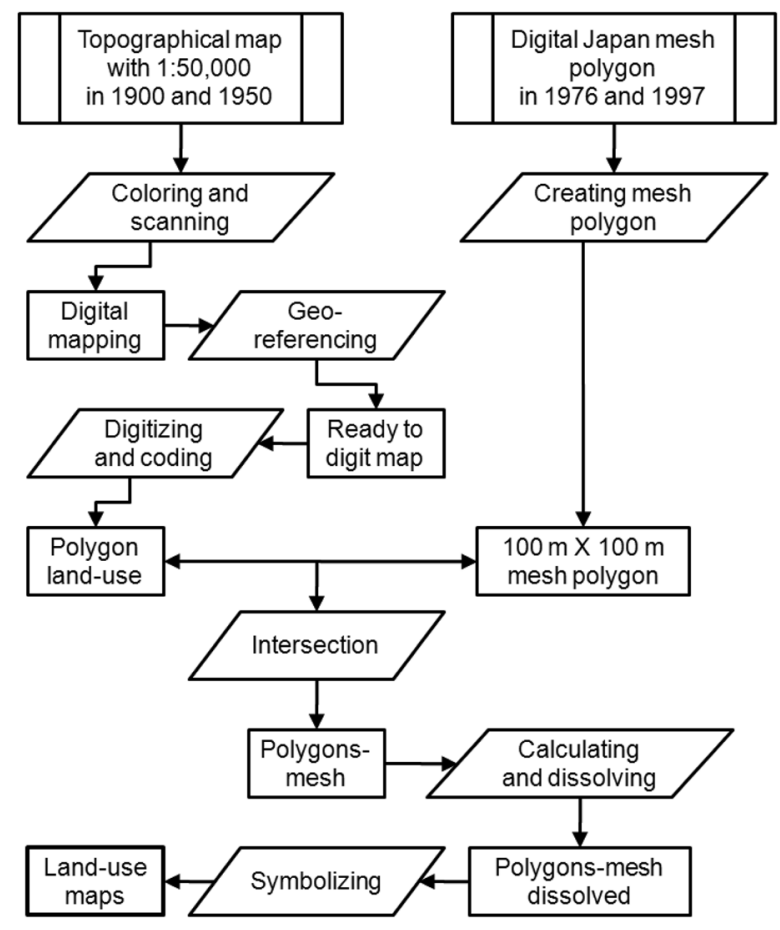

Fig. 6. Flow chart of making land-use maps from topographic maps by GIS.

land-use mesh was illustrated in Fig. 7. In detail, the procedure of making land-use map is as follows:

1) The basis of land-use boundary, which was called a colony boundary, was related to geographical features such as mountain and coastline. Those features were distinguishable in the old topographic paper map by markedly changing of the closest contour lines.

2) In the old topographic paper map, the vicinity to the land-use boundary was highlighted with color in order to facilitate the recognition of the land-use boundary.

3) The old topographic paper map was then read with the digital scanner using 300 dpi resolutions, A1 size, and converted to the form of TIFF RGB file.

4) In GIS, the scanned images were registered by assigning coordinates to their corners and converting them into the raster files.

5) The colored lines were traced by on-screen digitizing method. They classified into land-use categories such as forest, agriculture, urban, river, sea, and seashore polygons. After digitizing, all polygons were integrated and merged.

6) A unique identification number (code) was attributed to each land-use categories to make it noticeable during the union process.

7) The union process was made to join land-use polygons and mesh polygons.

8) In the dissolving process, which was to determine one land-use type for one mesh polygon, the land-use code with the maximum area value was assigned as land-use code of the mesh.

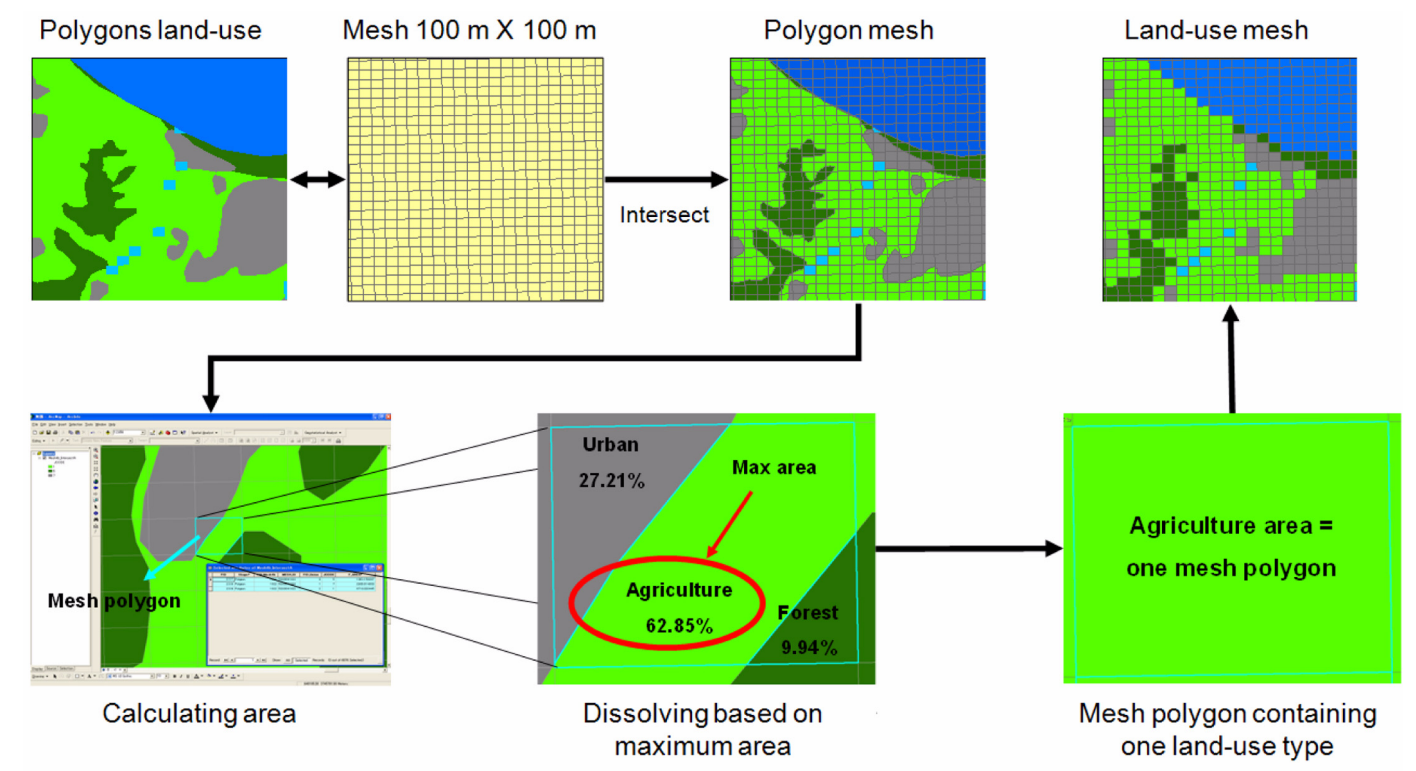

Fig. 7. Process of intersecting, calculating area, and conversion from land-use polygon into land-use mesh. 

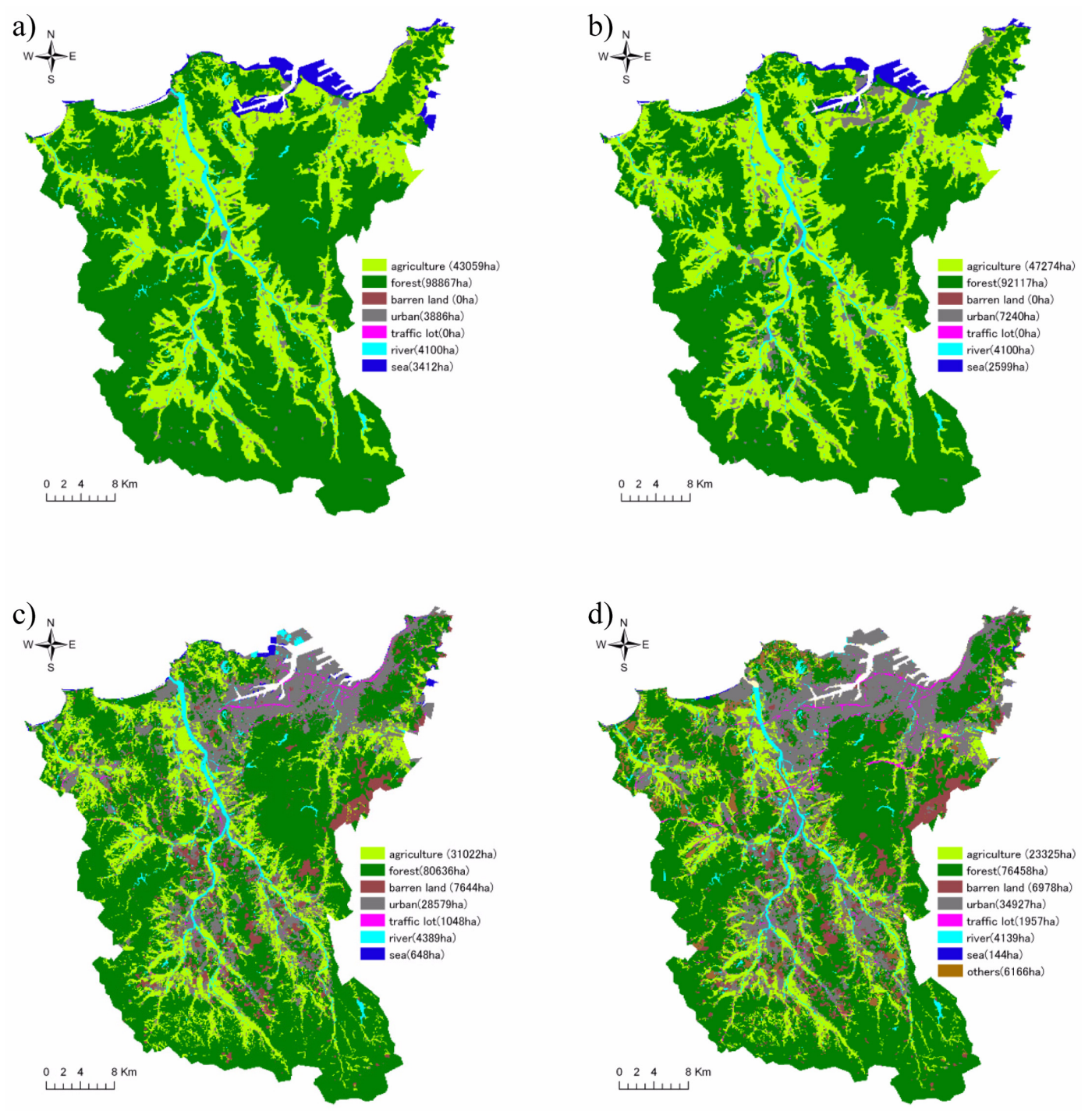

Fig. 8. Developed land-use maps of the KCD in a 1900, b 1950, c 1976, and d 1997.

9) Land-use maps were created using the results of those GIS process above.

\section{Results and Discussion}

\subsection{Spatial and temporal land-use changes over} the last 100 years

The new created land-use maps over the last 100 years were used to carry out an analysis of land-use changes using GIS technology (Fig. 8). By utilizing land-use maps of 1900, 1950, 1976, and 1997, land-use pattern changes in the KCD were analyzed based on $100 \mathrm{~m}$ mesh scale. In the land-use maps of 1900 and 1950, the existence of barren land area was not clearly visible, since coal mining activities promoted by big scale companies just started in 1900. In this year, the rapid coal development increased the coal production. This development continued until 1950 where a lot of space was used as mining related facilities location. At the same time, traffic lot area was counted as zero in land-use maps 1900 and 1950, because there was no big scale road, which was distinguished from old topographic maps, in this area until 1950. Moreover, it was found that agriculture area was $23.5 \%$ of the total KCD area, forest area was $67.8 \%$, and urban area was $2.7 \%$ in 1900 . It was noted that some of the sea area was included in the defined administrative boundary in the Northern part, where the land was bordered 


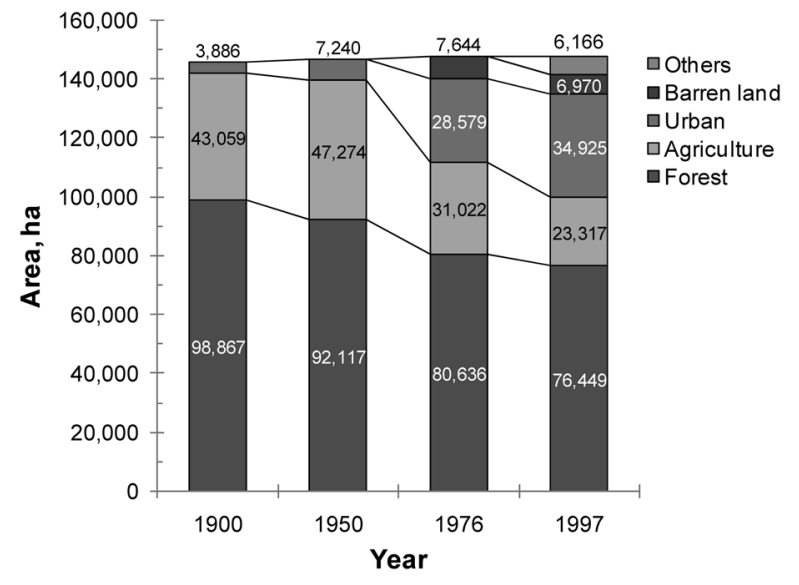

Fig. 9. Composition of land-use categories of the KCD in 1900, 1950, 1976, and 1997.

by the sea, and it was assumed as future reclaimed land. In 1950 , agriculture and urban area was increased to $32.2 \%$, forest area was decreased to $62.8 \%$. The increasing phenomena of urban area continued in 1976, counted as $19.3 \%$ of the total area. At the same time, agriculture and forest area was decreased to $21 \%$ and $54.5 \%$ respectively. In addition, the occurrence of barren land, which was counted as $5.2 \%$ of the total area, transformed the pattern of agricultural, forest and urban area in the KCD. In 1997, 4.3\% of agriculture area was decreased in contrary to the increase of urban area for $5.3 \%$ from 1976. In the same year, forest area was reduced to $0.6 \%$ and the barren land was increased to $0.5 \%$. Fig. 9 illustrates the land-use compositions (forest, agricul- ture, urban, barren land, and others) of the KCD, in 1990, 1950, 1976 and 1997. The analysis on land-use changes indicated that a significant different land-use pattern was found in the $\mathrm{KCD}$, in which coal mining was developed around World War II.

\subsection{Detailed land-use changes between 1900 and} 1950

The simulation of agriculture and forest area changed to other land-use categories between 1900 and 1950 was shown in Fig. 10. From the analysis on the land-use transition pattern, it can be noted that agriculture played a predominant role particularly in the plain area in the Onga River basin as a main river in this district in 1900. Moreover, the availability of water from the river to agriculture irrigation determined the initial pattern of agriculture development. Population of the KCD in 1900 was small and distributed in the agricultural village established to take advantage of the possibilities of irrigation from the Onga River. Population of some towns such as Nakama, Nogata, and Tagawa reflected the urban settlements in this district. The development of all of the towns was carved out of potentially useful agricultural land, although the area was very small compared to the forest and agriculture area that dominated the district at this time.

In 1950, the demand of food supply was increased and agriculture continued to be prime economic activity. Urban
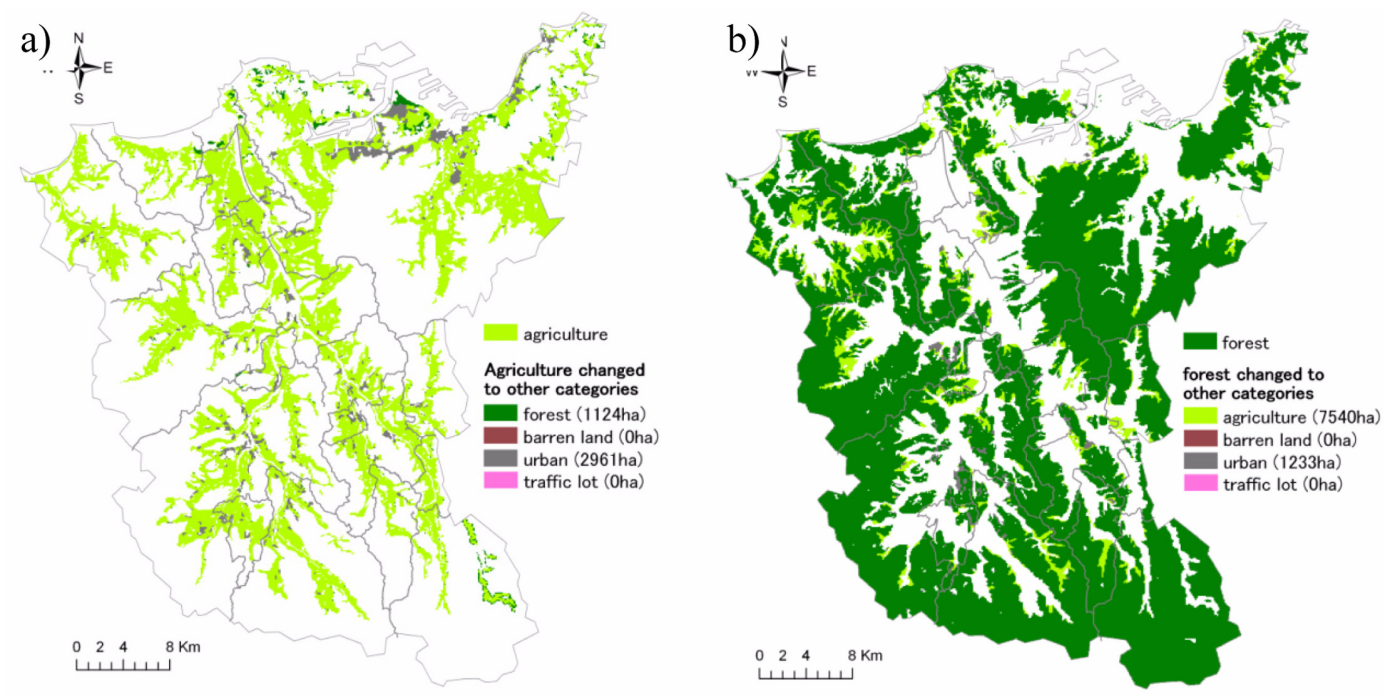

Fig. 10. Simulation of a agriculture and $\mathbf{b}$ forest area changed to other land-use categories from 1900 to 1950 .

J. Soil \& Groundwater Env. Vol. 18(4), p. 40 49, 2013 
growth appeared in several places such as in the surroundings of Tagawa, Nogata, Iizuka, and Kitakyushu, following the pattern of agriculture area in 1900. Although urban growth spread in all directions in the $\mathrm{KCD}$, the growth of the late 1970s began favoring in Kitakyushu town as the advance development of steel industry which was commenced since 1901. Furthermore, coal mining industry, which was developed to support the energy for the overall Japanese economy since 1900, also consumed the green field in the KCD. In 1903, the total coal output produced by big scale coal mining companies was approximately 5,050,000 tons (Murakushi, 1979). As the coal industry was developed and had been operated in 1950, the influx people to the KCD caused the increasing of urban area. Therefore, urban area was counted from house, school, and coal mining facilities related to mining industry during the period between 1900 and 1950 .

\subsection{Detailed land-use changes between 1950 and 1976}

The area of agriculture that was changed to other land-use categories between 1950 and 1976 was shown in Fig. 11. In 1976, urban land was rapidly developed in Nakama, Iizuka, Tagawa, and Nogata cities. In the land-use maps, barren land also commenced to distribute particularly in the peak mining period between 1950 and 1976. In the land-use maps of 1900 and 1950, the existence of barren land area was not clearly visible, since coal mining activities promoted by big scale companies just started in 1900. However, it was estimated that barren land existed in some limited areas. The vast coal mining industries were gradually ceased in the late 1970s. Thereafter, 7,644 hectares of barren land appeared in 1976 and distributed around the coal mining facilities and mine sites. From the total area of barren land in 1976, 1,388 hectares were resulted from formerly agriculture land and 5,992 hectares were resulted from formerly forest land. In 1976, 8,360 hectares forest land was developed from agriculture land as a result of planting enterprises promoted by Japanese government. At the same time, the existence of traffic lot (553 hectares) from agriculture land in 1950 was considered as the result of increasing social capital. Urban land in former agriculture land (13,197 hectares) was close to the urbanization area that tremendously progressed since 1900. Furthermore, it was also showed that the area of forest land was changed to other land-use categories between 1950 and 1976. In 1976, agriculture land from formerly forest land in 1950 (counted as 6,266 hectares), barren land from forest land (5,992 hectares), and urban from forest land (7,903 hectares) have shown a significant increase. Traffic lot resulted from formerly forest land (counted as 258 hectares) was also considered as the increase of social capital that was arranged by government in the period between 1950 and 1976.
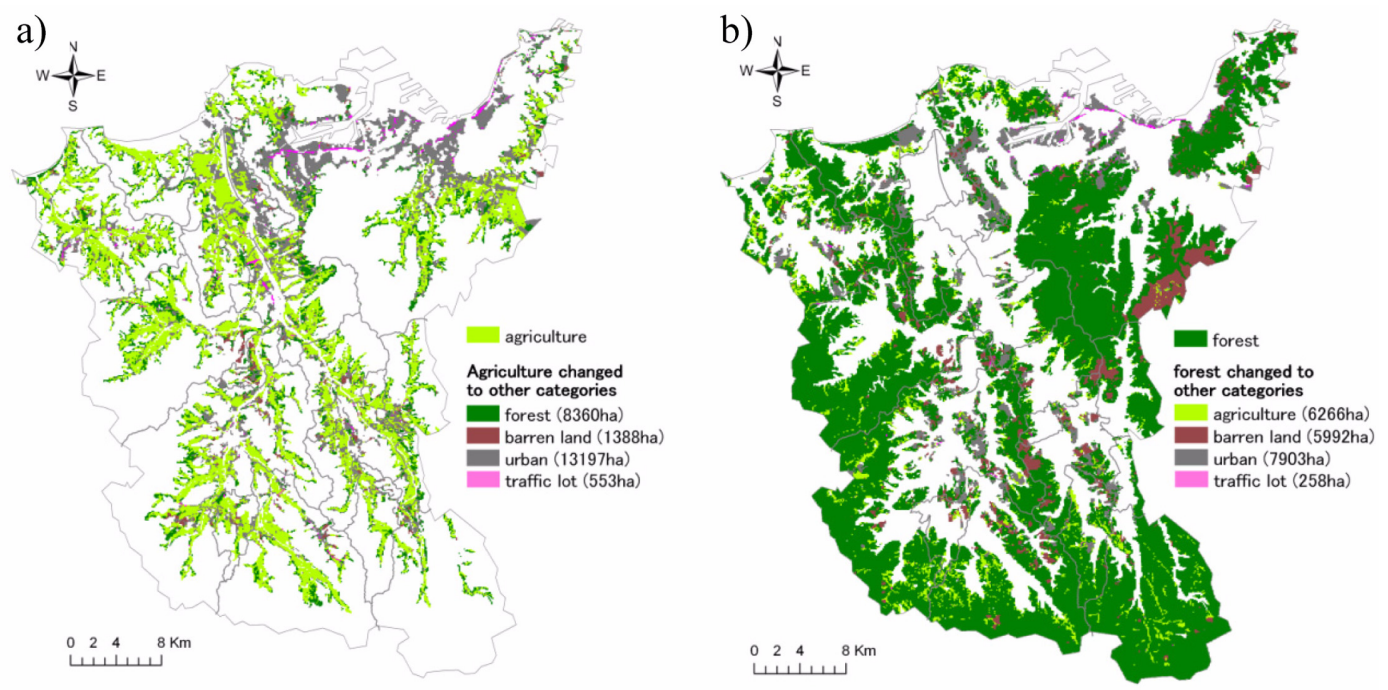

Fig. 11. Simulation of a agriculture and $\mathbf{b}$ forest area changed to other land-use categories from 1950 to 1976. 

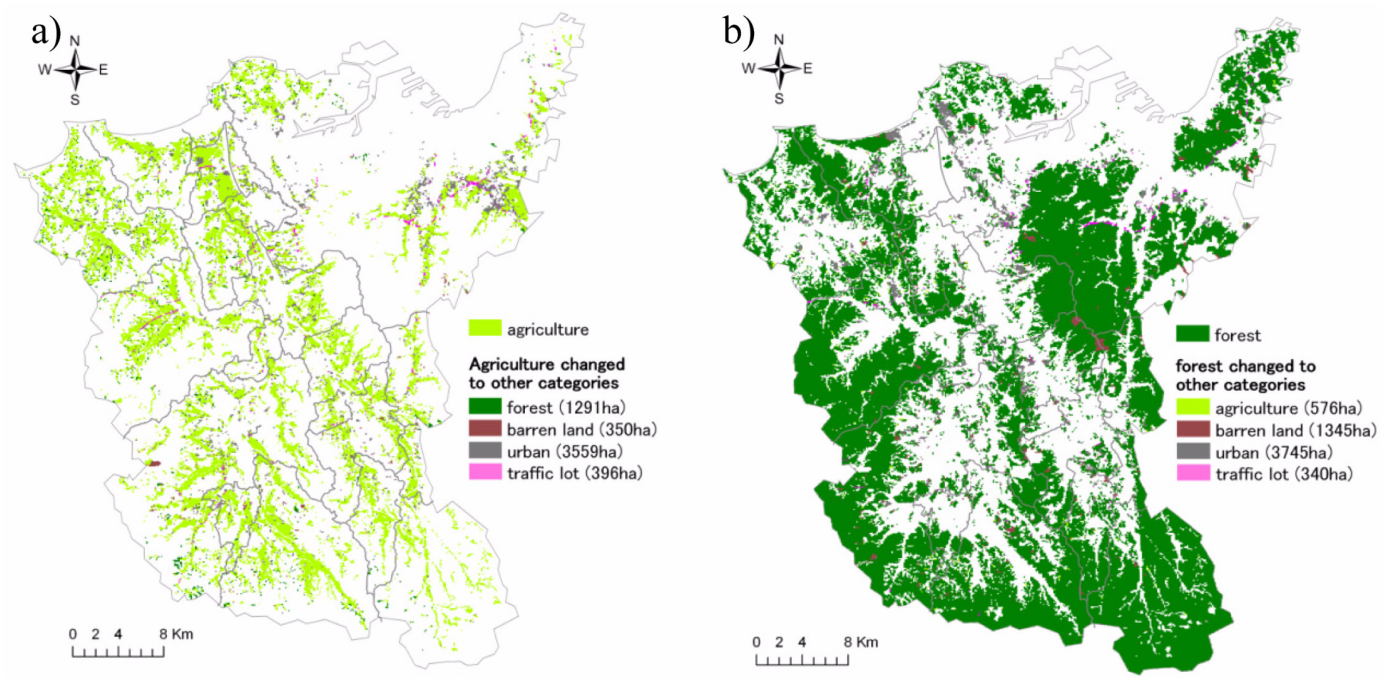

Fig. 12. Simulation of a agriculture and $\mathbf{b}$ forest area changed to other land-use categories from 1976 to 1997.

a)

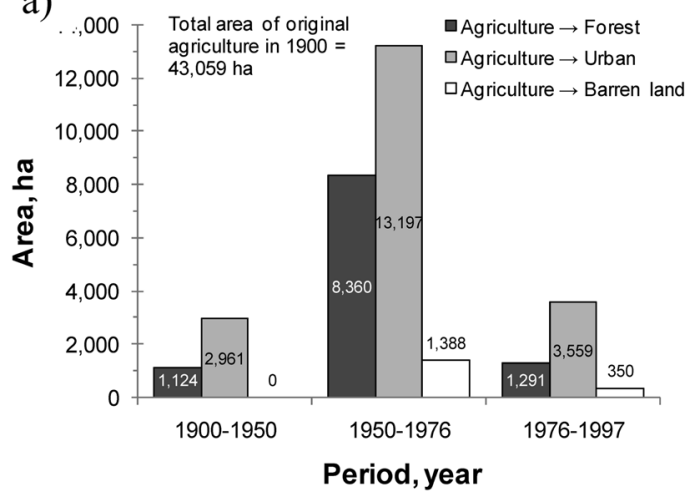

b)

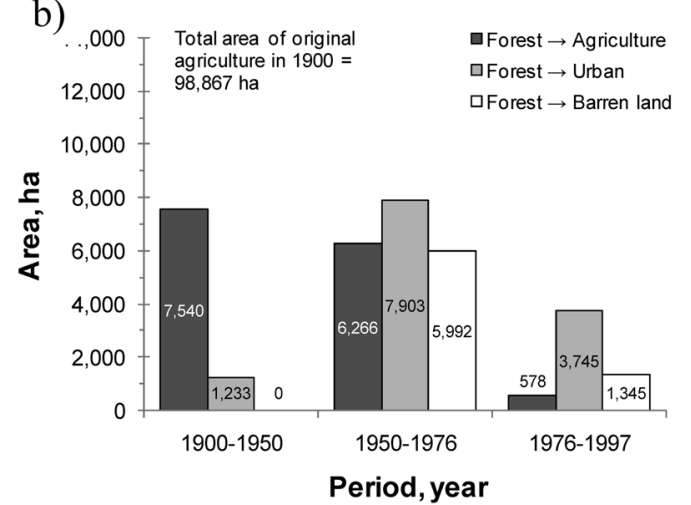

Fig. 13. Changes of a agriculture and $\mathbf{b}$ forest land to other land-use categories from 1900 to 1997.

\subsection{Detailed land-use changes between 1976 and} 1997

The area of agriculture and forest land which was changed to other land-use categories between 1976 and 1997 was shown in Fig. 12. In 1997, total barren land area in the KCD was calculated and counted as 6,978 hectares. This barren land was decreased by $1 \%$ after the mining activities closed in the late 1970s and government carried out specific efforts on the remediation of barren land up to recent days. At the same time, the increase of traffic lot (396 hectares) was resulted from social capital development since 1950. (Fig. 13 a) explains that agriculture land area was dramatically changed to forest, urban, and barren land in the period between 1950 and 1976. It can be noted that $19.4 \%$ from the total agriculture area in 1900 was changed to forest land due to planting enterprise that was promoted by the Japanese government. Similarly, the change of agriculture land to barren land was mostly due to the mine closure and counted as $3.2 \%$. The development of urban use due to urbanization showed the highest percentage among others that was $30.7 \%$ from total agriculture area in 1900. (Fig. 13 b) explains that much of forest land was also transformed to agriculture, urban, and barren land in the period between 1950 and 1976. In this period, $6 \%$ of total forest area in 1900 was transformed to agriculture land due to the development and extension of rice field for food demand.

\section{Conclusions}

In the $\mathrm{KCD}$, land-use changes were examined by summa- 
rizing different land-use conditions in the last 100 years and identifying particular causes of different uses of the land in different temporal context. The utilization of a series of developed land-use maps, which were performed by the aid of Geographic Information Systems (GIS), indicated that there was a significant difference of land-use pattern in the KCD before and after the peak of mining activities. Landuse analysis showed that agriculture and forest land was decreased in contrast to the increase of urban area and barren land in the last 100 years. In the beginning of 1900, the coal production in the KCD was rapidly increased due to the modernization of the coal industry by big capital that was continued until 1970s. During the period of 1900 to 1950 , the large number of people was entered into the city, which was one of the few areas offering a large number of jobs in the coal mines and related fields. Therefore, the increase of urbanization was found in the surrounding of extracted coal area such as Tagawa city, Iizuka city, and Nogata city in 1950. Furthermore, the development of coal mining industries in the KCD between 1900 and 1976 caused significant changes of barren land in 1976. However, the existence of barren land area was not clearly visible in land-use maps 1900 and 1950 due to the fact that coal mining activities promoted by big scale companies were just started in 1900 and the existence was limited only in some areas.

\section{Acknowledgements}

This paper was a part of doctoral research thesis that was carried out in Kyushu University and supported by Japanese Ministry of Education, Culture, Sports, Science, and Technology. Paper composition and review were carried out in Seoul National University under BK21 Safe \& Sustainable Infrastructure Research Group and supported by Post Doctoral Course Program of National Institute of Environmental Research, Republic of Korea. This research is also financially supported by Republic Korea Ministry of Envi- ronment as "Green Remediation Research Center for OrganicInorganic Combined Contamination (The GAIA Project2012000550002)". We thank all the contributors of this paper to make it success.

\section{References}

Aspinall, R. and Pearson, D., 2000, Integrated geographical assessment of environmental condition in water catchments: Linking landscape ecology, environmental modeling and GIS, $J$. Environ. Manage., 59, 299-319.

Campagna, M., 2006, GIS for Sustainable Development, CRC Press, Boca Raton, FL.

Chadwick, M.J., Highton, N.K., and Lindman, N., 1987, Environmental Impacts of Coal Mining and Utilization, Pergamon Press, NY.

Esaki, T., 2003, Land degradation through developments and its remediation, In: The Review of Japan Macro-Engineers Society, 16(1), 473-480.

Genske, D.D., 2003, Urban Land: Degradation, Investigation, and Re-mediation, Springer, Germany.

Longley, P.A., Goodchild, M.F., Maguire, D.J., and Rhind, D.W., 2001, Geographic Information Systems and Science, Willey, NY.

Murakushi, N., 1979, Coal Mining. Dev. Econ., 17, 461-483.

Okuno-Fujiwara, M., 1991, International policy in Japan: A political economy view, In: Trade with Japan: Has the Door Opened Wider Krugman P (ed), Chicago-London, University of Chicago Press.

Richards, I.G. and Palmer, J.P., 1993, The Reclamation of Former Coal Mines and Steelworks, Elsevier Science BV, Amsterdam.

Shapira, P., 1990, Industrial restructuring and economic development strategies in a Japanese steel town: The case of Kitakyushu, Town plan. Rev., 61(4), 389-412.

Tomlinson, R., 2003, Thinking about GIS: Geographical Information System Planning for Managers, ESRI Press, Redlands, CA. 